\title{
KARAKTERISTIK KEMASAN AKTIF DARI FILM GELATIN IKAN DENGAN PENAMBAHAN EKSTRAK DAUN JERUJU (Acanthus ilicifolius)
}

\section{Characteristics of Active Packaging from Fish Gelatin Film Incorporated with Acanthus ilicifolius Leaf Extract}

\author{
Rahmi Nurdiani ${ }^{1,2^{*}}$, Abdul Aziz Jaziri ${ }^{1,2}$ dan Fitri Septa Puspita ${ }^{1}$ \\ ${ }^{1}$ Program Studi Teknologi Hasil Perikanan, Fakultas Perikanan dan IImu Kelautan, Universitas Brawijaya, \\ JI. Veteran No.16, Malang, Jawa Timur, Indonesia \\ ${ }^{2}$ Bioseafood Research Group, Fakultas Perikanan dan IImu Kelautan, Universitas Brawijaya, \\ Jl. Veteran No.16, Malang, Jawa Timur, Indonesia \\ *Korespondensi Penulis: rahmi_nurdiani@ub.ac.id
}

Diterima: 20 Oktober 2019; Direvisi: 14 Januari 2020; Disetujui: 3 Juni 2020

\begin{abstract}
ABSTRAK
Kemasan aktif memiliki fungsi yang lebih luas dalam menjaga kualitas suatu produk. Salah satu bahan baku kemasan aktif adalah gelatin dengan penambahan senyawa aktif. Penelitian ini dimaksudkan untuk mempelajari karakteristik dan bioaktivitas kemasan aktif dari gelatin ikan ayam-ayam (Abalistes stellaris) dengan penambahan ekstrak daun jeruju (Acanthus ilicifolius) sebesar $0 \%, 1 \%, 3 \%, 5 \%$ dan $7 \%$. Kemasan aktif yang dihasilkan diamati karakteristik dan bioaktifitasnya yang meliputi ketebalan, kuat tarik, elongasi, transmisi uap air, kadar air, $\mathrm{pH}$, aktivitas antioksidan dan aktivitas antibakteri. Hasil analisa sidik ragam menunjukkan penambahan ekstrak daun jeruju berpengaruh nyata $(p<0,05)$ terhadap ketebalan, aktivitas antioksidan dan aktivitas antibakteri dari kemasan aktif berbahan gelatin yang dihasilkan, namun tidak berpengaruh nyata $(p>0,05)$ terhadap kuat tarik, elongasi dan transmisi uap air. Kemasan aktif dari gelatin ikan ayam-ayam dengan penambahan ekstrak daun jeruju $7 \%$ memiliki ketebalan $143,01 \mu \mathrm{m}$, mampu menghambat $65,45 \%$ radikal bebas DPPH dan menghasilkan zona hambat bakteri berkisar antara 2,18-2,61 mm. Hasil penelitian ini menunjukkan gelatin yang terbuat dari kulit dan sisik ikan ayam-ayam dengan penambahan ekstrak daun jeruju memiliki potensi untuk dikembangkan menjadi kemasan aktif.
\end{abstract}

KATA KUNCI : kemasan aktif, Acanthus ilicifolius, gelatin ikan

\begin{abstract}
Packaging has an important function in maintaining the quality of product. Active packaging can be made from gelatin as basic material with addition of bioactive substances. The purpose of this research was to study the characteristics and bioactivity of active packaging made from staryy triggerfish (Abalistes stellaris) gelatin incorporated with 0, 1, 3, 5, and 7\% of Acanthus ilicifolius leaf extract. The active pakaging was observed for its charateristics and bioactivity including thickness, elongation, tensile strength, water vapor transmission, moisture content, $\mathrm{pH}$, antioxidant activity, and antibacterial activity of active packaging. The statistical analyses showed that the addition of $\underline{A}$. ilicifolius leaf extracts significantly affected $(p<0.05)$ the thickness, antioxidant activity, and antibacterial activity of active packaging. Active packaging from fish gelatin containing $7 \%$ of A. ilicifolius extract with $143.01 \mu \mathrm{m}$ thickness, was able to inhibit $65.45 \%$ DPPH free radical and resulted in 2.18-2.61 $\mathrm{mm}$ inhibition zone. It was suggested that starry triggerfish gelatin and $\underline{A}$. ilicifolius leaf extract have a potential to be developed as active packaging.
\end{abstract}

KEYWORDS: active packaging, Acanthus ilicifolius, fish gelatin

\section{PENDAHULUAN}

Kemasan bahan pangan didefinisikan sebagai pembungkus atau wadah untuk melindungi bahan pangan dari gangguan atau kontaminasi dari sumber fisik, kimia, dan biologis, memperpanjang umur simpan dan menambah nilai jual dari bahan pangan (Muin, Diah, \& Folita, 2017; Prasad \& Kochhar, 2014). Kemasan makanan yang umum digunakan masyarakat ialah kemasan plastik. Kemasan plastik dipilih karena fleksibel dan transparan. Namun, plastik memiliki kelemahan antara lain: tidak tahan panas, tidak mudah terurai secara alami, dan berpotensi mencemari 
produk yang berisiko bagi keamanan dan kesehatan konsumen (Sari, Manurung, \& Permadi, 2008). Nugroho, Basito, dan Katri (2013), menyatakan bahwa salah satu alternatif untuk pengemasan pangan yang ramah lingkungan adalah penggunaan kemasan alami.

Beberapa tahun terakhir, telah berkembang kemasan aktif dari bahan alami yang bersifat biodegradable yang bersumber dari biopolimer yang dapat diperbaharui (Sutono, Doddy, \& Pranoto, 2013). Kemasan aktif adalah suatu konsep kemasan inovatif untuk menjaga mutu dan memperpanjang masa simpan produk, di mana bahan aktif yang ditambahkan pada kemasan tersebut dapat berinteraksi dengan produk (makanan) dan lingkungannya (Suppakul, Miltz, Sonneveld, \& Bigger, 2003). Kemasan biodegradable dapat dibuat dari karbohidrat, lemak, protein, atau kombinasi dua atau lebih bahan makromolekul tersebut (Negara \& Simpen, 2014). Salah satu biopolimer yang dapat digunakan sebagai bahan baku kemasan adalah gelatin karena merupakan makromolekul protein yang memiliki sifat fungsional seperti hidrokoloid, dapat membentuk film tipis yang elastis, transparan dan kuat (Julianto, Ustadi, \& Amir, 2011).

Gelatin dapat diperoleh dari bahan yang mengandung kolagen seperti kulit, sisik, dan tulang. Kulit dan sisik ikan ayam-ayam (Abalistes stellaris) merupakan salah satu bahan yang dapat dimanfaatkan untuk pembuatan gelatin. Pengolahan ikan ayamayam asap, menghasilkan limbah berupa kulit dan sisik yang cukup banyak dan mudah didapat. Limbah padat berupa kulit dan juga sisik ikan diperoleh dari proses pemisahan daging ikan ayam-ayam dengan kulitnya, yang dilakukan sebelum proses pengasapan (Jaziri, Muyasyaroh, \& Firdaus, 2019). Tekstur kulit ikan ayam-ayam yang tebal dan berbeda dari kulit ikan jenis lainnya berpotensi sebagai sumber gelatin halal. Beberapa penelitian menunjukkan bahwa gelatin ikan dapat diproduksi menjadi kemasan aktif dengan penambahan beberapa bahan aktif (Lee, Yang, \& Song, 2016; Tongnuanchan, Benjakul, \& Prodpran, 2012; Wu et al., 2013). Salah satu bahan aktif yang berpotensi untuk ditambahkan adalah ekstrak mangrove dari daun jeruju (Acanthus ilicifolius) yang mengandung senyawa polifenol, alkaloid dan flavonoid. Ekstrak tersebut memiliki bioaktivitas sebagai antiinflamasi, antioksidan, hepatoprotektif, antileukemia, antikanker, antimikroba, antivirus, antijamur dan sebagai insektisida alami (Irawanto, Hendrian, \& Mangkoedihardjo, 2014; Wostmann \& Liebezeit, 2008), sehingga dapat ditambahkan sebagai senyawa aktif pada kemasan pangan.

Penelitian ini dilakukan untuk mengetahui karakteristik dan bioaktivitas kemasan aktif dari bahan gelatin dengan penambahan ekstrak daun jeruju.

\section{BAHAN DAN METODE}

\section{Bahan}

Bahan yang digunakan dalam penelitian ini meliputi bahan untuk ekstraksi gelatin ikan, bahan untuk ekstraksi daun jeruju (A. ilicifolius), bahan untuk pembuatan kemasan aktif dan bahan untuk uji kemasan aktif. Bahan-bahan yang digunakan untuk pembuatan gelatin ikan di antaranya adalah kulit dan sisik ikan ayam-ayam ( $A$. stellaris) hasil samping dari proses pengasapan ikan di UKM yang berada di Tuban (Jawa Timur), aquades, asam asetat, $\mathrm{NaOH}$ (Merck, USA), dan kertas saring. Metanol (Merck, USA) digunakan untuk ekstraksi daun jeruju. Penggunaan metanol didasarkan atas pertimbangan keefektifan sebagai pengekstraksi bahan aktif dari tanaman. Menurut BPOM kandungan maksimal metanol dalam bahan pangan tidak boleh melebihi 0,01\% (BPOM, 2016). Oleh karena itu, pelarut metanol dalam ekstrak daun jeruju harus benar-benar sudah menguap sebelum dicampurkan dengan gelatin. Kemasan aktif dibuat menggunakan bahan-bahan gelatin ikan, gliserol (Merck, USA), ekstrak daun jeruju dan aquades, sedangkan bahan yang digunakan untuk analisis kemasan aktif antara lain DPPH, bakteri uji (Staphylococcus aureus, Escherichia coli, Salmonella, dan Bacillus subtilis).

\section{Metode}

Penelitian ini menggunakan metode eksperimen, dengan desain Rancangan Acak Lengkap (RAL) di mana konsentrasi ekstrak daun jeruju sebesar $0 \%$, $1 \%, 3 \%, 5 \%$ dan $7 \%$ sebagai faktor tunggal, percobaan dilakukan sebanyak 4 kali ulangan. Parameter yang diamati meliputi ketebalan, kuat tarik, elongasi, transmisi uap air, kadar air, pH, aktivitas antioksidan dan aktivitas antibakteri dari kemasan aktif. Penelitian dilakukan dalam tiga tahapan yaitu pembuatan gelatin, ekstraksi daun jeruju dan pembuatan kemasan aktif. Data yang diperoleh kemudian dianalisis dengan sidik ragam (ANOVA) dan dilanjutkan dengan uji Tukey.

\section{Pembuatan gelatin}

Pembuatan gelatin yang dilakukan berdasarkan metode Gudmunson dan Hafsteinsson (1997), diawali dengan menyiapkan/memperkecil ukuran kulit dan sisik ikan ayam-ayam segar kemudian merendamnya dalam $\mathrm{NaOH}$ 0,1 M dengan rasio 1:5 (w/v). Campuran dihomogenasi menggunakan magnetic stirrer pada suhu kamar selama 2 jam, larutan alkali diganti setiap satu jam. Kulit dan sisik kemudian dicuci dengan aquades sampai $\mathrm{pH} 7$. Setelah itu kulit dan sisik direndam dalam larutan asam asetat konsentrasi 0,6 $M$ dengan rasio 1:5 (w/v) selama 2 jam sambil diaduk terus menerus secara perlahan. Kulit dan sisik yang 
mulai membengkak, kemudian dicuci dengan aquades sampai $\mathrm{pH}$ 7. Selanjutnya gelatin diekstrak menggunakan aquades dengan rasio 1:3 (w/v), dilakukan di dalam waterbath suhu $55^{\circ} \mathrm{C}$ selama 4 jam, lalu disaring menggunakan kertas saring Whatman no. 42. Filtrat dituang di atas loyang kemudian dikeringkan dalam oven suhu $55^{\circ} \mathrm{C}$ selama 48 jam. Lembaran gelatin kemudian dihaluskan menggunakan grinder hingga diperoleh gelatin bubuk.

\section{Ekstraksi daun jeruju (A. ilicifolius)}

Sebelum dilakukan esktraksi, daun jeruju dikering anginkan selama kurang lebih 3 minggu, dan digiling menjadi serbuk. Proses ekstraksi dilaksanakan berdasarkan metode Paputungan, Wonggo dan Kaseger (2017).Seratus gram serbuk daun jeruju dimasukkan ke dalam botol kaca gelap, ditambah pelarut metanol $90 \%$ dengan rasio $1: 3(\mathrm{w} / \mathrm{v})$, dan dimaserasi selama 3x24 jam. Setiap 24 jam pelarut metanol diganti. Hasil maserasi kemudian disaring dengan kertas saring Whatman no. 42. Filtrat dikeringkan dengan vacuum rotary evaporator pada suhu $65^{\circ} \mathrm{C}$ sehingga diperoleh ekstrak kental.

\section{Pembuatan kemasan aktif}

Kemasan aktif dibuat berdasarkan penelitian Chin, Lyn, dan Hanani (2017) dengan beberapa modifikasi. Lima gram gelatin bubuk dilarutkan dalam $100 \mathrm{~mL}$ akuades dan dipanaskan di atas hot plate stirrer pada $50{ }^{\circ} \mathrm{C}$ selama 30 menit, kemudian ditambahkan gliserol sebanyak $0,5 \%(\mathrm{v} / \mathrm{v})$. Pemanasan dilanjutkan pada suhu $45^{\circ} \mathrm{C}$ selama 15 menit. Setelah itu ekstrak daun jeruju dengan konsentrasi $0,1,3,5$, dan $7 \%$ (w/ w) ditambahkan ke dalam larutan gelatin, dan diaduk pada suhu kamar $\left(25^{\circ} \mathrm{C}\right)$ hingga ekstrak mangrove benar benar larut. Campuran kemudian dituang ke dalam loyang ukuran $20 \times 20 \mathrm{~cm}^{2}$ secara merata lalu dikeringkan dalam oven pada suhu $55^{\circ} \mathrm{C}$ selama 1820 jam hingga kering. Cetakan kemudian dikeluarkan dan dibiarkan pada suhu ruang selama 10 menit. Secara perlahan dilakukan proses pengelupasan atau peeling dengan ujung pisau sehingga lapisan film terlepas.

\section{Analisis kemasan aktif}

\section{Analisis asam amino gelatin}

Sampel gelatin sebanyak $0,1 \mathrm{~g}$ dilarutkan dalam 5 $\mathrm{mL} 6 \mathrm{~N} \mathrm{HCl}$, dihidrolisis selama 22 jam pada suhu $110{ }^{\circ} \mathrm{C}$ kemudian difiltrasi. Sebanyak $500 \mu \mathrm{L}$ filtrat sampel dicampur dengan $40 \mu \mathrm{L}$ alpha amino butyric acid (AABA) dan $460 \mu \mathrm{L}$ aquabides. Sebanyak $40 \mu \mathrm{L}$ standar asam amino, $40 \mu \mathrm{L}$ internal standar AABA dan $920 \mu \mathrm{L}$ aquabides dicampur dan dihomogenisasi untuk memperoleh larutan standar. Sebanyak $10 \mu \mathrm{L}$ campuran sampel atau standar, ditambah dengan
$70 \mu \mathrm{L}$ AccQ-fluor borate dan $20 \mu \mathrm{L}$ reagen fluor $\mathrm{A}$ (6aminoquinolyl-N-hydroxysuccinimidyl carbamate), lalu dihomogenisasi dengan vortex dan didiamkan selama 1 menit. Sampel ataupun larutan standar yang telah dihomogenkan dengan vortex kemudian dipanasi pada suhu $55^{\circ} \mathrm{C}$ selama 10 menit dan sampel siap disuntikkan ke Ultra Performance Liquid Chromatography (UPLC). Sebanyak $1 \mu \mathrm{L}$ sampel disuntikan ke dalam UPLC H-Class yang dilengkapi dengan kolom ACCQ-Tag Ultra C18 $(2,1 \times 100 \mathrm{~mm})$ dan detektor PDA, analisis dilakukan pada suhu 49 ${ }^{\circ} \mathrm{C}$, dengan fase gerak berupa sistem komposisi gradien (asetonitril dan akuades), laju alir 0,7 mL per menit, panjang gelombang $260 \mathrm{~nm}$ (Suryanti, Marseno, Indrati, \& Irianto, 2017). Larutan standar asam amino diperlukan untuk menghitung konsentrasi asam amino yang terdapat dalam sampel.

\section{Ketebalan}

Ketebalan kemasan aktif diukur menggunakan mikrometer sekrup dengan ketelitian $0,01 \mathrm{~mm}$ pada lima tempat yang berbeda yaitu di keempat sisi dan bagian tengah sampel kemasan aktif (ukuran sampel $20 \times 20 \mathrm{~cm}^{2}$ ). Nilai ketebalan kemasan aktif dihitung dari rata-rata hasil pengukuran di lima tempat pengukuran (Chae \& Heo, 1997).

\section{Kuat tarik dan elongasi}

Kuat tarik dan presentase pemanjangan (elongasi) kemasan aktif diukur menggunakan Tensile Strength and Elongation Tester Industries model SSB 0500 (Akili, Ahmed, \& Suyatna, 2012). Sebelum diuji, kemasan aktif disimpan di dalam desikator yang memiliki $\mathrm{RH} 75 \%$ selama 24 jam. Nilai gaya maksimum untuk menarik sampel kemasan aktif sampai putus akan muncul pada layar alat dan dicatat untuk diolah dan dianalisa. Kuat tarik ditentukan berdasarkan beban maksimum pada saat kemasan aktif putus terhadap luas film (MPa), sedangkan presentase pemanjangan didasarkan atas pemanjangan kemasan saat kemasan putus (\%).

\section{Transmisi uap air}

Uji transmisi uap air yang mengacu pada metode ASTM (1993) dilakukan dengan memotong kemasan aktif dengan diameter $\pm 3,5 \mathrm{~cm}$ dan diletakkan di antara dua wadah (gelas minuman). Wadah pertama berisi air sedangkan wadah kedua diberi silica gel yang telah diketahui beratnya (konstan). Masa uap air yang melewati kemasan aktif diukur dengan menimbang kemasan aktif sebelum uji dan setelah 24 jam. Transmisi uap air dihitung dengan rumus:

Transmisi uap perhari $\left(\mathrm{g} / \mathrm{m}^{2}\right.$ hari $)=\frac{W}{A}$

Keterangan:

W : Perubahan berat kemasan aktif per 24 jam (g)

A : Luas area kemasan aktif $\left(\mathrm{m}^{2}\right)$ 


\section{Derajat keasaman $(p H)$}

Serbuk gelatin sebanyak $0,2 \mathrm{~g}$ dilarutkan dalam $20 \mathrm{~mL}$ aquades pada suhu $80^{\circ} \mathrm{C}$. Larutan kemudian dihomogenkan dengan magnetic stirer dan diukur dengan $\mathrm{pH}$ meter pada suhu kamar untuk mengetahui derajat keasamannya $(\mathrm{pH})(\mathrm{BSI}, 1975)$.

\section{Kadar air}

Sampel sebanyak $5 \mathrm{~g}$ diletakkan dalam cawan kosong yang sudah ditimbang beratnya kemudian dipanaskan di dalam oven pada suhu 100-102 ${ }^{\circ} \mathrm{C}$ selama 6 jam. Besaran kadar air dari sampel (\%) adalah berat air yang hilang setelah pemanasan dibagi dengan berat sample awal (BSN,1995).

Kadar air $=\frac{\mathrm{W}_{1}-\mathrm{W}_{2}}{\text { Berat sampel }} \times 100 \%$

\section{Aktivitas antioksidan}

Pengujian aktivitas antioksidan dengan metode DPPH (Hanani, Yee, \& Khaizura, 2019), diawali dengan penyiapan sampel, yaitu $25 \mathrm{mg}$ kemasan aktif (mengandung $0 \%, 1 \%, 3 \%, 5 \%$, atau $7 \%$ ekstrak daun jeruju) dilarutkan dalam $5 \mathrm{~mL}$ metanol. Setiap sampel $(0,1 \mathrm{~mL})$ dicampur dengan 3,9 ml larutan DPPH 0,02 $\mathrm{mmolL}^{-1}$. Campuran dihomogenkan dan diinkubasi selama 30 menit dalam suasana gelap pada suhu kamar, kemudian dibaca nilai absorbansinya pada panjang gelombang $517 \mathrm{~nm}$. Persentase (\%) peredaman ditentukan menggunakan rumus:

$\%$ Peredaman $=\frac{A_{0}-A_{1}}{A_{0}} \times 100 \%$

Keterangan:

$A_{0}$ : absorbansi kontrol (metanol + DPPH) tanpa sampel $A_{1}$ : absorbansi sampel uji (sampel + DPPH)

\section{Aktivitas antibakteri}

Uji daya hambat menggunakan media Muller Hinton Agar (MHA) sebagai media pertumbuhan bakteri (Putra, 2015). Uji ini diawali dengan merendam blank disc pada larutan kemasan aktif selama 15 menit. Larutan kemasan aktif yang digunakan pada pengujian ini terbuat dari $5 \mathrm{~g}$ gelatin bubuk yang dilarutkan dalam $100 \mathrm{~mL}$ akuades, ditambahkan gliserol sebanyak $0,5 \%(\mathrm{v} / \mathrm{v})$ dan diperkaya dengan ekstrak daun jeruju dengan konsentrasi $0 \%, 1 \%, 3 \%, 5 \%, 7 \%$. Blank disc yang telah direndam ditempelkan pada media MHA yang telah diinokulasi dengan bakteri uji dengan kepadatan $3 \times 10^{8} \mathrm{cfu} / \mathrm{mL}$, dan diinkubasi selama 16 jam. Zona bening yang terbentuk setelah inkubasi diukur menggunakan jangka sorong. Pengukuran dilakukan dengan mengukur tiga sisi dari zona bening yaitu secara horizontal, vertikal dan juga miring. Ukuran yang diperoleh kemudian di rata-rata. Diameter zona bening dinyatakan dalam satuan milimeter $(\mathrm{mm})$.

\section{HASIL DAN PEMBAHASAN}

\section{Karakteristik Gelatin}

Nilai asam amino gelatin kulit ikan ayam-ayam dapat dilihat pada Tabel 1. Nilai asam amino sangat menentukan karakteristik gelatin sebagai bahan pembuat kemasan (film), khususnya nilai asam imino (imino acids) salah satunya prolin. Tingginya asam imino dapat meningkatkan kekuatan film karena mampu meningkatkan ikatan hidrogen dan menghasilkan molekul yang kompak (Suderman, Isa, \& Sarbon, 2018).

Selain itu asam amino glisin menyusun 30 persen dari komposisi asam amino yang mencirikan gelatin, diikuti dengan prolin dan hidroksiprolin. Hasil uji asam amino jenis L-Glisin dan L- Prolin gelatin dari kulit ikan ayam-ayam diperoleh masing-masing sebesar $29,60 \%$ dan $12,53 \%$, dan komponen tersebut lebih besar dari L-Glisin dan L-Prolin gelatin kulit ikan tuna (Nurilmala, Agoes, \& Rofi, 2017) dan gelatin komersial (Nurilmala, 2004) yang disajikan pada Tabel 1.

\section{Karakteristik Kemasan Aktif}

\section{Kenampakan kemasan aktif}

Kenampakan kemasan aktif dari gelatin kulit ikan ayam-ayam yang ditambahkan dengan ekstrak daun jeruju dipresentasikan pada Gambar 1.

Kenampakan kemasan aktif ini menunjukkan bahwa semakin tinggi presentase ekstrak daun jeruju yang ditambahkan pada gelatin kulit ikan ayam-ayam menghasilkan perubahan warna hijau pada kemasan aktif yang semakin pekat. Kenampakan warna hijau kemasan aktif juga dapat dipresentasikan sebagai berikut $E>D>C>B>A$, di mana $E$ paling hijau, yang diikuti dengan $D, C, B$, dan $A$. Warna yang terbentuk pada kemasan aktif sangat dipengaruhi oleh pigmen yang terkandung dalam bahan aktif yang ditambahkan. Warna ekstrak daun jeruju adalah hijau pekat sehingga semakin tinggi konsentrasi ekstrak yang ditambahkan, maka warna kemasan aktif akan semakin hijau pekat. Hal ini sesuai dengan penelitian yang dilaporkan oleh Khasanah et al. (2017), yang menyatakan bahwa semakin banyak persentase ekstrak daun sereh yang ditambahkan pada kemasan aktif, maka warna hijau pada kemasan aktif menjadi 
Tabel 1. Kandungan asam amino gelatin ikan ayam-ayam dibandingkan dengan gelatin kulit ikan tuna dan gelatin komersial

Table 1. Amino acid composition of starry triggerfish gelatin compared to tuna fish skin gelatin and commercial tuna skin gelatin

\begin{tabular}{lccc}
\hline \multicolumn{1}{c}{ Asam Amino/Amino Acids } & $\begin{array}{c}\text { Gelatin Ikan Ayam- } \\
\text { Ayam/Starry } \\
\text { Triggerfish Gelatin } \\
(\%)\end{array}$ & $\begin{array}{c}\text { Gelatin Kulit Ikan } \\
\text { Tuna Sirip Kuning/ } \\
\text { Tuna Skin Gelatin } \\
(\%)^{*}\end{array}$ & $\begin{array}{c}\text { Gelatin Komersial/ } \\
\text { Commercial Gelatin } \\
(\%)^{\star *}\end{array}$ \\
\hline L-Serin/L-Serine & 4.42 & 3.90 & 2.18 \\
L-Asam glutamat/L-Glutamic acid & 8.98 & 7.30 & - \\
L-Fenialanin/L-Phenylalanine & 3.03 & 3.10 & 1.92 \\
L-Isoleusin/L-Isoleucine & 1.24 & 1.10 & 1.13 \\
L-Valin/L-Valine & 3.25 & 2.10 & 1.60 \\
L-Alanin/L-Alanine & 9.15 & 8.10 & 10.24 \\
L-Arginin/L-Arginine & 10.57 & 10.40 & 8.95 \\
L-Glisin/L-Glycine & 29.60 & 26.40 & 23.01 \\
L-Lisin/L-Lysine & 3.50 & 2.80 & 2.80 \\
L-Asam aspartat/L-Aspartic acid & 4.88 & 3.00 & 4.93 \\
L-Leusin/L-Leucine & 2.62 & 2.50 & - \\
L-Tirosin/L-Tyrosine & 0.83 & 0.60 & 0.15 \\
L-Prolin/L-Proline & 12.53 & 10.40 & 12.34 \\
L-Threonin/L-Threonine & 4.00 & 3.70 & 2.87 \\
L-Histidin/L-Histidine & 1.38 & 1.00 & 0.03 \\
\hline
\end{tabular}

Sumber/Annotation : ${ }^{*}\left(\right.$ Nurilmala, Agoes, \& Rofi, 2017), ${ }^{* *}($ Nurilmala, 2004)

semakin pekat sesuai dengan warna oleoresin yang dikandung oleh daun sereh.

Karakteristik fisik dari kemasan aktif gelatin kulit ikan ayam-ayam dengan penambahan ekstrak daun jeruju disajikan pada Tabel 2. Karakteristik fisik dari kemasan mencerminkan kemampuan kemasan dalam melindungi makanan (Rubilar et al., 2013).

\section{Ketebalan}

Ketebalan kemasan aktif dengan penambahan ekstrak jeruju berbeda nyata $(p<0,05)$ dan berkisar antara 140,70-143,01 $\mu \mathrm{m}$. Hasil ini lebih tinggi dibandingkan dengan edible film dengan penambahan propagul mangrove lindur yang nilai ketebalannya berkisar antara 79,8-98,7 $\mu \mathrm{m}$ (Nurinda, Alamsjah, \&

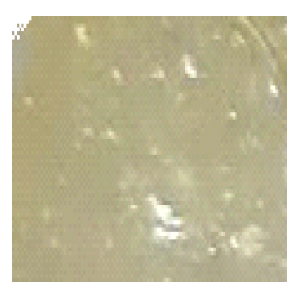

A

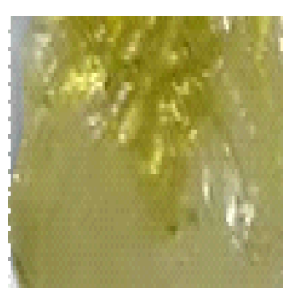

$B$

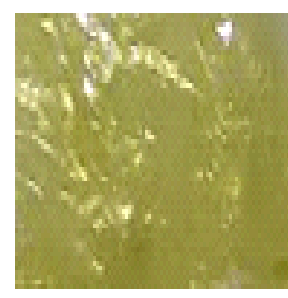

C

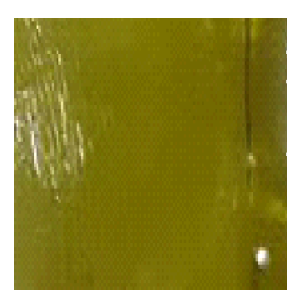

$D$

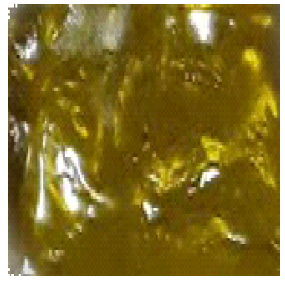

E

Gambar 1. Kenampakan kemasan aktif dari gelatin kulit ikan ayam-ayam dengan penambahan ekstrak daun jeruju (A. ilicifolius) $0 \%(A), 1 \%(B), 3 \%(C), 5 \%(D)$ dan $7 \%(E)$

Figure 1. The appearance of active packaging from starry triggerfish gelatin incorporated with $\underline{A}$. ilicifolius leaf extract $0 \%(A), 1 \%(B), 3 \%(C), 5 \%(D)$ and $7 \%(E)$ 
Tabel 2. Karakteristik fisik kemasan aktif dari gelatin kulit ikan ayam-ayam dengan penambahan ekstrak daun jeruju ( $A$. ilicifolius)

Table 2. Physical characteristics of active packaging from starry triggerfish gelatin incorporated with $\underline{A}$. ilicifolius leaf extract

\begin{tabular}{|c|c|c|c|c|c|}
\hline \multirow[t]{2}{*}{ Parameter/Parameters } & \multicolumn{5}{|c|}{$\begin{array}{c}\text { Konsentrasi Ekstrak Daun Jeruju/ } \\
\text { Concentration of A. ilicifolius Leaf Extract }\end{array}$} \\
\hline & $0 \%$ & $1 \%$ & $3 \%$ & $5 \%$ & $7 \%$ \\
\hline Ketebalan/Thickness $(\mu \mathrm{m})$ & $140.70 \pm 0.01^{a}$ & $141.44 \pm 0.10^{\mathrm{b}}$ & $141.78 \pm 0.09^{b}$ & $142.11 \pm 0.03^{b c}$ & $143.01 \pm 0.22^{c}$ \\
\hline Kuat tarik / Tensile strength (MPa) & $12.14 \pm 0.01^{\mathrm{a}}$ & $11.78 \pm 0.04^{\mathrm{a}}$ & $11.67 \pm 0.01^{\mathrm{a}}$ & $11.50 \pm 0.01^{\mathrm{a}}$ & $11.49 \pm 0.05^{a}$ \\
\hline Elongasi/Elongation (\%) & $16.85 \pm 0.04^{\mathrm{a}}$ & $17.01 \pm 0.15^{\mathrm{a}}$ & $17.18 \pm 0.11^{\mathrm{a}}$ & $17.25 \pm 0.11^{\mathrm{a}}$ & $17.29 \pm 0.11^{\mathrm{a}}$ \\
\hline $\begin{array}{l}\text { Laju transmisi uap air/ Water } \\
\text { vapour transmission rate }\left(\mathrm{g} / \mathrm{m}^{2} \text { hari }\right)\end{array}$ & $13.43 \pm 0.11^{\mathrm{a}}$ & $13.37 \pm 0.04^{\mathrm{a}}$ & $13.35 \pm 0.13^{\mathrm{a}}$ & $13.33 \pm 0.06^{a}$ & $13.30 \pm 0.05^{\mathrm{a}}$ \\
\hline $\mathrm{pH} / \mathrm{pH}$ & $6.81 \pm 0.08^{\mathrm{a}}$ & $6.55 \pm 0.07^{\mathrm{ab}}$ & $6.41 \pm 0.19^{b}$ & $6.35 \pm 0.07^{b}$ & $6.18 \pm 0.07^{b}$ \\
\hline Kadar air/Moisture content (\%) & $6.00 \pm 0.41^{\mathrm{a}}$ & $6.20 \pm 0.50^{\mathrm{a}}$ & $6.50 \pm 0.82^{\mathrm{a}}$ & $6.60 \pm 0.75^{a}$ & $6.80 \pm 0.65^{a}$ \\
\hline
\end{tabular}

Keterangan/Note: Baris dengan anotasi yang berbeda menunjukkan beda nyata $(\mathrm{p}<0,05) /$ Row with different anotation shows significant difference $(p<0.05)$

Sudarno, 2015). Ketebalan film tergantung pada kadar padatan dalam larutan pembentuk film. Selain dipengaruhi oleh komponen penyusun kemasan aktif, ketebalan juga dipengaruhi oleh luas plat cetakan dan volume suspensi kemasan yang dicetak (Chin et al., 2017).

Peningkatan ketebalan kemasan aktif disebabkan volume suspensi kemasan yang dituangkan dalam plat sama, tetapi presentase penambahan ekstrak daun jeruju berbeda sehingga dapat meningkatkan total padatan dan polimer penyusun matriks film. Peningkatan ketebalan pada kemasan aktif ini sejalan dengan Hanani, Yee, dan Khaizura (2019) yang melaporkan bahwa semakin tinggi ekstrak kulit delima yang ditambahkan pada kemasan aktif dari gelatin ikan, maka semakin tinggi ketebalan kemasan aktif tersebut, di mana ketebalan kemasan aktif yang diperoleh berkisar 72,50-106,25 $\mu \mathrm{m}$ dengan penambahan $1 \%$ - $5 \%$ ekstrak kulit delima

\section{Kuat tarik}

Nilai kekuatan tarik kemasan aktif pada penelitian ini berkisar 12,14 sampai 11,49 MPa (Tabel 2), di mana terjadi penurunan pada nilai kekuatan tariknya dengan bertambahnya konsentrasi ekstrak jeruju tetapi nilai tersebut tidak berbeda nyata $(p>0,05)$. Hal ini dimungkinkan bahwa ekstrak daun jeruju sangat lemah membentuk ikatan silang dengan gelatin kulit ikan dalam pembuatan kemasan aktif. Hal ini sejalan dengan penelitian yang dilaporkan oleh Chin et al. (2017), di mana penambahan ekstrak lidah buaya 5\% sampai $9 \%$ pada pembuatan kemasan aktif dari gelatin ikan mengakibatkan penurunan nilai kekuatan tariknya. Hasil serupa dilaporkan oleh Hanani et al. (2019), pada penambahan tepung kulit buah delima 3\%, 4\%, dan $5 \%$ pada kemasan aktif dari gelatin ikan $(p>0,05)$.

\section{Elongasi}

Nilai elongasi kemasan aktif berbahan gelatin kulit ikan ayam-ayam dengan penambahan ekstrak daun jeruju berkisar antara 16,85 sampai 17,29\% (Tabel 2). Sebagaimana nilai kekuatan tarik, penambahan ekstrak jeruju juga tidak signifikan $(p>0,05)$ terhadap peningkatan nilai elongasi kemasan aktif. Hal ini sejalan dengan penelitian dari Hanani et al. (2019) pada penambahan ekstrak kulit buah delima 1\% sampai $5 \%$ yang juga tidak menunjukkan pengaruh pada nilai elongasi kemasan aktif dari gelatin ikan. Namun, nilai elongasi dari kemasan aktif gelatin dengan ekstrak jeruju ini jauh lebih tinggi daripada nilai elongasi kemasan aktif gelatin dengan bubuk ekstrak delima (Hanani et al., 2019) yang berkisar 1,88-2,09\%. Hal ini dimungkinkan karena ketebalan dan kekuatan tarik sampel kemasan aktif yang diuji lebih tinggi dari temuan Hanani et al. (2019) pada kemasan aktif dengan bubuk ekstrak kulit delima. Nilai elongasi yang rendah menunjukkan bahwa film yang dihasilkan bersifat rapuh (Chambi \& Grosso, 2011).

\section{Laju transmisi uap air}

Laju transmisi uap air merupakan salah satu sifat fisik kemasan yang sangat penting yang menunjukkan 
kemampuan kemasan dalam meminimalisasi interaksi antara produk yang dikemas dengan lingkungan sekitar (Hanani et al., 2019). Laju transmisi uap air kemasan aktif dengan penambahan ekstrak jeruju yaitu antara 13,30-13,43 $\mathrm{g} / \mathrm{m}^{2}$ hari. Hasil ini lebih rendah dibandingkan dengan laju transmisi uap air edible film propagul mangrove lindur dengan nilai laju transmisi uap air antara 15,71-22,88 $\mathrm{g} / \mathrm{m}^{2}$ hari (Nurinda, Alamsjah, \& Sudarno, 2015). Lebih rendahnya nilai laju transmisi uap air pada kemasan aktif yang diuji dibandingkan dengan edible film propagul mangrove lindur karena diduga terjadi pembentukan ikatan silang antara gelatin kulit ikan ayam ayam dan polisakarida dalam ekstrak daun jeruju yang mengurangi ruang kosong yang tersedia untuk pergerakan molekul air.

\section{pH}

Nilai pH kemasan aktif dari gelatin kulit ikan ayamayam yang ditambahkan dengan ekstrak daun jeruju berkisar antara 6,18 dan 6,81 (Tabel 2). Semakin tinggi persentase ekstrak daun jeruju yang ditambahkan pada pembuatan kemasan aktif dari gelatin kulit ikan ayam-ayam, maka nilai $\mathrm{pH}$ yang dihasilkan semakin rendah walau tidak berbeda nyata pada penambahan $1 \%$ sampai $7 \%(p>0,05)$. Ekstrak daun jeruju diketahui memiliki pH asam (Andria, 2017). pH gelatin ikan ayam-ayam cenderung normal, namun dengan penambahan ekstrak jeruju yang bersifat asam maka terjadi penurunan $\mathrm{pH}$ kemasan aktif yang di hasilkan.

\section{Kadar air}

Tinggi rendahnya kandungan air dalam kemasan aktif dipengaruhi oleh bahan dasar dan bahan tambahan dalam pembuatannya. Nilai kadar air kemasan aktif gelatin kulit ikan ayam-ayam meningkat dengan semakin banyaknya penambahan ekstrak daun jeruju (Tabel 2). Nilai kadar air kemasan aktif dengan penambahan ekstrak jeruju berkisar antara $6,00 \%$ dan $6,80 \%$, namun, perbedaan antar perlakuan tidak signifikan $(p>0,05)$. Kandungan air dari ekstrak jeruju dapat menambah fleksibilitas dari kemasan aktif yang dihasilkan, di mana fleksibilitas tersebut terlihat pada nilai elongasi kemasan aktif yang diuji sebesar 17,01-17,29\%. Hal ini sebagaimana pengaruh ekstrak aloe vera terhadap film dari chitosan (Khoshgozaran-Abras, Aizizi, Hamidy, \& BagheripoorFallah, 2012). Ismail, Mansor, Majeed, dan Man (2016) menyatakan bahwa kandungan air bahan pembentuk kemasan dapat berfungsi sebagai plasticizer sehingga berpengaruh positif terhadap elongasi dari kemasan.

\section{Aktivitas antioksidan}

Aktivitas antioksidan (yang dinyatakan sebagai presentase peredaman DPPH) kemasan aktif ini pada konsentrasi $5 \mathrm{mg} / \mathrm{mL}$ berkisar antara $15,48 \%$ sampai $65,45 \%(p<0,05)$ (Gambar 2). Semakin banyak presentase ekstrak daun jeruju yang ditambahkan pada kemasan aktif gelatin kulit ikan ayam-ayam,

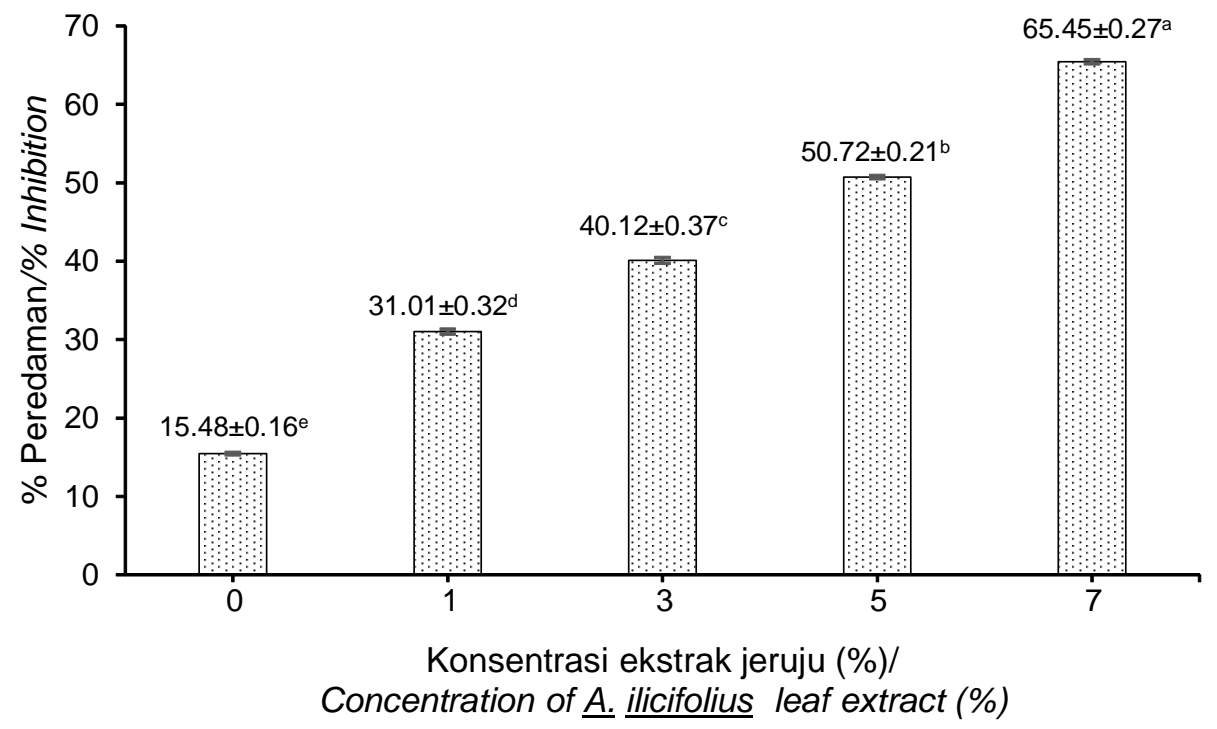

Keterangan/Note :Batang dengan anotasi yang berbeda menunjukkan beda nyata $(p<0,05) / B a r$ with different anotation shows significant difference $(p<0.05)$

Gambar 2. Aktivitas antioksidan kemasan aktif gelatin kulit ikan ayam-ayam dengan penambahan ekstrak daun jeruju (A. ilicifolius)

Figure 2. Antioxidant activity of active packaging from starry triggerfish gelatin incorporated with $\underline{A}$. $\underline{\text { ilicifolius }}$ leaf extract 
semakin tinggi juga aktivitas antioksidan yang dihasilkan. Hal ini menandakan bahwa ekstrak daun jeruju mengandung senyawa aktif antioksidan. Handayani, Najib, dan Wati (2018) melaporkan bahwa ekstrak daun jeruju memiliki aktivitas antioksidan yang kuat dengan nilai $\mathrm{IC}_{50} 34,659 \mu \mathrm{g} / \mathrm{mL}$. Hasil penelitian ini sejalan dengan penelitian Hanani et al. (2019) yang melaporkan bahwa semakin banyak ekstrak kulit buah delima yang ditambahkan pada kemasan aktif dari gelatin ikan, maka semakin tinggi aktivitas antioksidannya, di mana nilai peredaman DPPH berkisar 59,74\%-71,82\% dengan penambahan ekstrak buah delima $1 \%$ sampai $5 \%$ pada kemasan aktif gelatin ikan. Meskipun demikian, gelatin ikan ayamayam tanpa penambahan ekstrak daun jeruju mempunyai aktivitas peredaman DPPH sebesar $15,48 \%$, hal ini dikarekan tingginya kandungan asam amino glisin dan prolin pada gelatin ikan ayam-ayam. Nurilmala, Hizbullah, Karnia, Kusumaningtyas, dan Ochiai (2020) menyatakan bahwa tingginya kandungan glisin dan prolin menunjukkan tingginya aktivitas antioksidan pada gelatin ikan.

\section{Aktivitas antibakteri}

Aktivitas antibakteri dari kemasan aktif berbahan gelatin kulit ikan ayam-ayam dengan ekstrak daun jeruju terhadap bakteri $S$. aureus, E. coli, Salmonella sp. dan $B$. subtillis, menunjukkan pengaruh yang berbeda nyata $(p<0,05)$. Didapatkan zona hambat pada $S$. aureus sebesar 0,00-2,61 mm. Hasil ini lebih rendah dari zona hambat antibakteri edible film gelatin ikan dengan penambahan karvakrol (0,2-0,6\%) dengan besar zona hambat pada bakteri $S$. aureus antara 0,0-
2,7 cm (Neira, Martucci, Stejskal, \& Ruseckaite, 2019). Selain itu, zona hambat pada E. coli didapatkan hasil sebesar 0,00-2,13 $\mathrm{mm}$ dan lebih rendah dari zona hambat antibakteri edible film gelatin ikan dengan penambahan karvakrol dengan besar zona hambat pada E. coli antara 0,0-3,1 cm (Neira, et al., 2019). Hal ini dimungkinkan ekstrak daun jeruju yang digunakan masih ekstrak kasar, sebaliknya karvakrol yang ditambahkan pada pembuatan kemasan aktif gelatin ikan oleh Neira et al. (2019) adalah karvakrol murni (carvacrol (5-Isopropyl-2-methylphenol, CRV, $\geq$ 98\%), walaupun konsentrasi yang ditambahkan sedikit, yaitu 0,2-0,6\% pada pembuatan kemasan aktif gelatin ikan. Namun demikian, pada studi ini dibuktikan bahwa ekstrak daun jeruju memiliki kemampuan sebagai bahan aktif pada pembuatan kemasan gelatin untuk menghambat pertumbuhan mikroba dibandingkan larutan gelatin 5\% tanpa penambahan ekstrak aktif dari daun jeruji yang tidak memiliki aktivitas antibakteri.

Zona hambat Salmonella sp. pada studi ini didapatkan tertinggi pada konsentrasi ekstrak jeruju $7 \%$ yaitu sebesar 2,47 mm. Namun, hasil ini lebih rendah dari starch-based antimicrobial films yang mengandung $2 \%$ kulit buah delima dengan besar zona hambat pada bakteri Salmonella sebesar 10,22 mm (Ali et al., 2018). Zona hambat kemasan aktif gelatin dan ekstrak jeruju terhadap $B$. subtillis berkisar antara $0,00-2,18 \mathrm{~mm}$. Hasil ini jauh lebih rendah dari carboxymethyl cellulose/chitosan biguanidine hydrochloride edible film yang diperkaya dengan 1$5 \%$ minyak frankincense dengan zona hambat pada bakteri $B$. subtilis antara 18,23-32,40 mm (Salama,

Tabel 3. Zona hambat kemasan aktif gelatin kulit ikan ayam-ayam dengan penambahan ekstrak daun jeruju (A. ilicifolius)

Table 3. Inhibition zone of active packaging from starry trigger fish gelatin incorporated with $\underline{A}$. ilicifolius leaf extract

\begin{tabular}{ccccc}
\hline \multirow{2}{*}{$\begin{array}{c}\text { Konsentrasi Ekstrak Daun } \\
\text { Jeruju/Concentration of } \begin{array}{c}\boldsymbol{A} . \\
\text { ilicifolius Leaf Extract }\end{array}\end{array}$} & $\begin{array}{c}\text { Zona Hambat (mm) Kemasan Aktif Gelatin/Inhibition Zone (mm) of } \\
\text { Active Packaging from Starry Triggerfish Gelatin }\end{array}$ \\
\cline { 2 - 5 } & $\begin{array}{c}\text { Staphylococcus } \\
\text { aureus }\end{array}$ & $\begin{array}{c}\text { Escherichia } \\
\text { coli }\end{array}$ & Salmonella sp. & $\begin{array}{c}\text { Bacillus } \\
\text { subtillis }\end{array}$ \\
\hline $0 \%$ & - & - & - & - \\
$1 \%$ & - & $0.91 \pm 0.09^{\mathrm{c}}$ & - & - \\
$3 \%$ & $1.38 \pm 0.91^{\mathrm{c}}$ & $1.37 \pm 0.06^{\mathrm{b}}$ & $1.19 \pm 0.08^{\mathrm{c}}$ & $0.63 \pm 0.08^{\mathrm{c}}$ \\
$5 \%$ & $1.98 \pm 0.07^{\mathrm{b}}$ & $1.76 \pm 0.06^{\mathrm{a}}$ & $2.11 \pm 0.03^{\mathrm{b}}$ & $1.47 \pm 0.06^{\mathrm{b}}$ \\
$7 \%$ & $2.61 \pm 0.11^{\mathrm{a}}$ & $2.13 \pm 013^{\mathrm{a}}$ & $2.47 \pm 0.06^{\mathrm{a}}$ & $2.18 \pm 0.10^{\mathrm{a}}$ \\
\hline
\end{tabular}

Keterangan/Note: Notasi yang berbeda pada kolom yang sama menunjukkan berbeda nyata $(p<0,05) / D$ ifferent anotation in the same column shows significant difference $(p<0.05)$ 
Aziz, \& Sabaa, 2019). Hal ini dikarenakan minyak frankincense adalah murni dan memiliki kemampuan antibakteri yang sangat kuat (Hammer, Carson, \& Riley, 1999), sebaliknya ekstrak daun jeruju yang ditambahkan pada studi ini adalah ekstrak kasar.

\section{KESIMPULAN}

Penambahan ekstrak daun jeruju ( $A$. ilicifolius) ( $0 \%, 1 \%, 3 \%, 5 \%$, dan $7 \%)$ pada bahan pengemas dari gelatin berpengaruh nyata terhadap ketebalan, aktivitas antioksidan dan antibakteri dari kemasan aktif yang dihasilkan, namun tidak berbeda nyata terhadap kekuatan tarik, elongasi, laju transmisi uap air, dan kadar air. Perlakuan penambahan ekstrak jeruju 7\% pada kemasan, terbukti dapat menghambat kerja radikal bebas sampai $65,45 \%$ dan menghambat pertumbuhan bakteri S. aureus, E. coli, Salmonella sp., dan $B$. subtillis. Dengan demikian, penambahan ekstrak daun jeruju ke dalam larutan gelatin dapat menghasilkan kemasan aktif yang berpotensi dalam menghambat proses oksidasi dan menghambat perumbuhan bakteri bahan pangan yang dikemas sehingga akan memperpanjang masa simpan. Dalam pengaplikasiannya lebih lanjut sebagai kemasan bahan pangan, perlu diperhatikan residu larutan pengekstraksi bahan aktif seperti metanol yang mungkin tertinggal, untuk menjamin keamanan pangan.

\section{DAFTAR PUSTAKA}

Akili, M. S., Ahmad, U., \& Suyatna, N. E. (2012). Karakteristik edible film dari pektin hasil ekstraksi kulit pisang. Jurnal Keteknikan Pertanian, 26(1), 10-12.

Ali, A., Chen, Y., Liu, H., Yu, L., Baloch, Z., Khalid, S., ... Chen, L. (2019). Starch-based antimicrobial films functionalized by pomegranate peel. International Journal of Biological Macromolecules, 129, 1120-1126. https://doi.org/10.1016/j.jbiomac.2018.09.068

Andria, C. (2017). Kajian pembuatan minuman dari daun jeruju (Acanthus ilicifolius Linn). Skripsi. Jurusan Teknologi Hasil Pertanian. Fakultas Pertanian. Universitas Jambi.

American Society for Testing and Material (ASTM). (1993). Annual Book of ASTM Standards. Philadelphia : ASTM.

Badan Pengawasan Obat dan Makanan (BPOM). (2016). Peraturan Kepala Badan Pengawas Obat dan Makanan Republik Indonesia Nomor 14 Tahun 2016 Tentang Standar Keamanan dan Mutu Minuman Beralkohol. Jakarta, Indonesia.

Badan Standardisasi Nasional (BSN). (1995). Mutu dan cara uji gelatin. SNI 06-3735. Jakarta (ID) : BSN.

British Standards Institution (BSI). (1975). Methods for Sampling and Testing Gelatin (Physical and Chemical Methods). UK : BSI.
Chae, S., \& Heo, T. R. (1997). Production and properties of edible film using whey protein. Biotechnology and Bioprocess Engineering, 2, 122-125.

Chambi, H. N. M., \& Grosso, C. R. F. (2011). Mechanical and water vapor permeability properties of biodegradables films based on methylcellulose, glucomannan, pectin and gelatin. Food Science and Technology, 31(3), 739-746.

Chin, S. S., Lyn, F. H., \& Hanani, Z. A. N. (2017). Effect of aloe vera (Aloe barbadensis Miller) gel on the physical and functional properties of fish gelatin films as active packaging. Food Packaging and Shelf Life, 12,128-13.

Gudmunson, M., \& Hafsteinsson, H. (1997). Gelatin from cod skins as affected by chemical treatments. Journal of Food Science, 62(1), 37-47

Hammer, K. A., Carson, C. F., \& Riley, T. V. (1999). Antimicrobial activity of esential oils and other plant extracts. Journal of Applied Microbiology, 86(6), 985990.

Hanani Z. A. N., Yee F. C., \& Khaizura M. A. R. N. (2019). Effect of pomegranate (Punica granatum L.) peel powder on the antioxidant and antimicrobial properties of fish gelatin films as active packaging. Food Hydrocolloids, 89, 253-259.

Handayani, S., Najib, A., \& Wati, N. P. (2018). Uji aktivitas antioksidan ekstrak daun duruju (Acanthus ilicifolius L.) dengan metode perendaman radikal bebas 1,1diphenyil-2-picrylhidrazil (DPPH). Jurnal Fitofarmaka Indonesia, 5(2), 299-308.

Irawanto, R., Hendrian, R., \& Mangkoedihardjo, S. (2014). Konsentrasi logam berat (Pb dan $\mathrm{Cd}$ ) pada bagian tumbuhan akuatik Acanthus ilicifolius (Jeruju). Seminar Nasional Konservasi dan Pemanfaatan Sumberdaya Alam 2015. Solo, Universitas Sebelas Maret.

Ismail, S., Mansor, N., Majeed, Z., \& Man, Z. (2016). Effect of water and [Emim][OAc] as plasticizer on gelatinization of starch. Procedia Engineering, 148, 524-529.

Jaziri, A. A., Muyasyaroh, H., \& Firdaus, M. (2019). Karakterisitk gelatin kulit ikan ayam ayam (Abalistes stellaris) dengan praperlakuan konsentrasi asam sitrat. Journal of Fisheries and Marine Research, 3(2), 183-193.

Julianto, G. E., Ustadi, U., \& Amir, H. (2011). Karakterisasi edible film dari gelatin kulit nila merah dengan penambahan plasticizer sorbitol dan asam palmitate. Jurnal Perikanan, 8(1), 27-34.

Khasanah, L. U., Atmaka, W., Kurmiasari, D., Kawiji, K., Praseptiangga, \& Utami, R. (2017). Karakteristik kemasan kertas aktif dengan penambahan oleoresin ampas destilasi sereh dapur (Cymbopongon citratus). Agritech, 37(1), 59-68.

Khoshgozaran-Abras S., Azizi M.H., Hamidy Z., \& Bagheripoor-Fallah N. (2012). Mechanical, physicochemical and color properties of chitosan based-films as a function of aloe vera gel incorporation. Carbohydrate Polymers, 87(3), 2058-2062.

Lee, K. Y., Yang, H. J., \& Song, K. B. (2016). Application of a puffer fish skin gelatin film containing Moringa 
oleifera Lam. leaf extract to the packaging of Gouda cheese. Journal of Food Science and Technology, 53(11), 3876-3883.

Muin, R., Diah, A., \& Folita, M. (2017). Karakteristik fisik dan antimikroba edible film dari tepung tapioka dengan penambahan gliserol dan kunyit putih. Jurnal Teknik Kimia, 23(3), 191-198.

Negara, I. M. S., \& Simpen. (2014). Sintesis dan karakterisasi edible film berbahan baku gelatin hasil isolasi kulit dan ceker ayam broiler. Jurnal Kimia, 8(1), 120-126.

Neira, L. M., Martucci, J. F., Stejskal, N., \& Ruseckaite, R. A. (2019). Time-depend evolution of properties of fish gelatin edible films enriched with carvacrol during storage. Food Hydrocolloids, 94, 304-310.

Nugroho, A., Basito, \& Katri, R. B. (2013). Kajian pembuatan edible film tapioka dengan penambahan pektin beberapa jenis kulit pisang terhadap karakteristik fisik dan mekanik. Jurnal Teknosains Pangan, 2(1),1-12.

Nurilmala, M. (2004). Kajian potensi limbah tulang ikan keras (teleostei) sebagai sumber gelatin dan analisis karakteristiknya. Tesis. Bogor. Sekolah Pasca Sarjana. Institut Pertanian Bogor.

Nurilmala, M., Agoes, M. J., \& Rofi, A. D. (2017). Karakteristik gelatin kulit ikan tuna sirip kuning. Journal Pengolahan Hasil Perikanan Indonesia, 20(2), 339-350.

Nurilmala, M., Hizbullah, H. H., Karnia, E., Kusumaningtyas, E., \& Ochiai, Y. (2020). Characterization and antioxidant activity of collagen, gelatin, and the derived peptides from yellowfin tuna (Thunnus albacares) skin. Marine Drugs, 18(98), 1-12.

Nurinda, A. P., Alamsjah, A. M., \& Sudarno. (2015). Karakterisasi edible film dari pati propagul mangrove lindur (Bruguiera gymnorrhiza) dengan penambahan carboxymethyl cellulose (CMC) sebagai pemlastis. Jurnal IImiah Perikanan dan Kelautan, 7(2), 125-132.

Paputungan, Z., Wonggo, D., \& Kaseger, B. E. (2017). Uji fitokimia dan aktivitas antioksidan buah mangrove Sonneratia alba di desa nunuk kecamatan Pinolosian kabupaten Bolaang Mongondow Selatan. Jurnal Media Teknologi Hasil Perikanan, 5(3), 190-195.

Prasad, P., \& Kochhar, A. (2014). Active packaging in food industry: a review. Journal of Enviromental Science, Toxicology and Food Technology, 8(5), 134-141.

Putra, I. M. A. (2015). Uji aktivitas antibakteri ekstrak etanol daun sirsak (Annonae muricata L.) dengan metode difusi agar cakram terhadap Eschericia coli. Medicamento, 1(1), 15-19.

Rubilar, J. F., Cruz, R. M., Silva, H. D., Vicente, A. A., Khmelinskii, I., \& Vieira, M. C. (2013). Physicomechanical properties of chitosan films with carvacrol and grape seed extract. Journal of Food Engineering, 115(4), 466-474.

Salama, H. E.,Aziz M.S.A., \& Sabaa M. W..(2019). Development of antibacterial carboxymethyl cellulose/chitosan biguanidine hydrochloride edible films activated with frankincense essential oil. International Journal of Biological Macromolecules, 139, 1162-1167.

Sari, T. I., Manurung H. P., \& Permadi F. (2008). Pembuatan edible film dari kolang kaling. Jurnal Teknik Kimia, 4(15), 27-35.

Suppakul, P., Miltz, J., Sonneveld, K., \& Bigger, S. W.. (2003). Active packaging technologies with an emphasis on antimicrobial packaging and its applications. Jounal Food Science, 68, 408-420.

Suryanti, S., Marseno, D. W., Indrati, R., \& Irianto, H. E. (2017). Pengaruh jenis asam dalam isolasi gelatin dari kulit ikan nila (Oreochromis niloticus) terhadap karakteristik emulsi. AGRITECH, 37(4), 410-419.

Sutono, Doddy, \& Pranoto, Y. (2013). Ekstrak rumput laut (Kappaphycus alvarezii) sebagai cross linking agent pada pembentukan edible film gelatin kulit ikan nila hitam (Oreohromis mossambius). AGRITECH, 33(2), 168-175

Suderman, N., Isa, M. I. N., \& Sarbon, N. M. (2018). Characterization on the mechanical and physical properties of chicken skin gelatin films in comparison to mammalian gelatin films. IOP Conf. Series: Material Science and Engineering 440012033. doi:10.1088/1757-899X/440/1/012033

Tongnuanchan, P., Benjakul, S., \& Prodpran, T. (2012). Properties and antioxidant activity of fish skin gelatin film incorporated with citrus essential oils. Food Chemistry, 134(3), 1571-1579.

Wostmann, R., \& Liebezeit, G. (2008). Chemical composition of the mangrove holly Acanthus ilicifolius (Acanthaceae)-review and additional data. Senckenbergiana Maritima, 38(1), 31-37.

Wu, J., Chen, S., Ge, S., Miao, J., Li, J., \& Zhang, Q. (2013). Preparation, properties and antioxidant activity of an active film from silver carp (Hypophthalmichthys molitrix) skin gelatin incorporated with green tea extract. Food Hydrocolloids, 32(1), 42-51. 